\title{
Behind the fungus ball: pulmonary aspergillosis!
}

\author{
Louise Dunphy (1) , Edward McKeown
}

Respiratory Medicine, Royal Berkshire NHS Foundation Trust, Berkshire, UK

\section{Correspondence to}

Dr Louise Dunphy;

Louise.Dunphy@doctors.org.uk

Accepted 25 November 2020

\section{DESCRIPTION}

An 84-year-old man who resided in the UK was referred to the ENT department for investigation of his hoarse voice. Flexible nasoendoscopy confirmed a paralysed left vocal cord. His chest radiograph showed a large left upper lobe cavity (figure 1). He was referred to respiratory medicine for further investigation.

His comorbidities included chronic obstructive pulmonary disease (COPD), type 2 diabetes and hypertension. His medications included ramipril $5 \mathrm{mg}$ one time a day and metformin $500 \mathrm{mg}$ two times per day. He was an ex-smoker with a 70 packyear history. A CT scan of the neck and thorax showed chronic infection within the left upper lobe with a large cavity containing organising material suspicious for a mycetoma (figure 2). His beta-Dglucan level was negative and his galactomannan level at bronchoalveolar lavage was 0.5. His Aspergillus fumigatus-specific IgE was high $(0.41 \mathrm{kUA} / \mathrm{L}$, range $0-0.34$ ) and the diagnosis was rendered with microscopy and cultures demonstrating fungal spores and hyphae on staining.

Aspergillus is an ubiquitous fungus and the interplay between this pathogen and the hosts immune system determines which clinical syndrome is more likely to develop. Only a minority of those exposed to Aspergillus through inhalation will develop lung disease.

Invasive aspergillosis, implying invasion of lung tissue by hyphae as demonstrated on histology, develops in severely immunocompromised individuals, including those with neutropenia, a recognised classic risk factor, lung transplant recipients, haematopoietic stem cell transplant recipients and those taking steroids. It can also occur in non-neutropenic hosts, as in this case, after massive exposure to fungal spores or following corticosteroid use. ${ }^{1}$ In these hosts, angioinvasion is not a common feature,

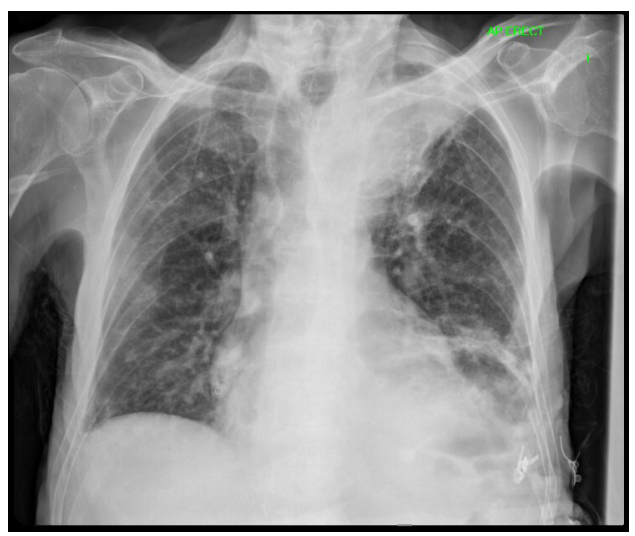

Figure 1 The patient's chest radiograph showing a large left upper lobe cavity.

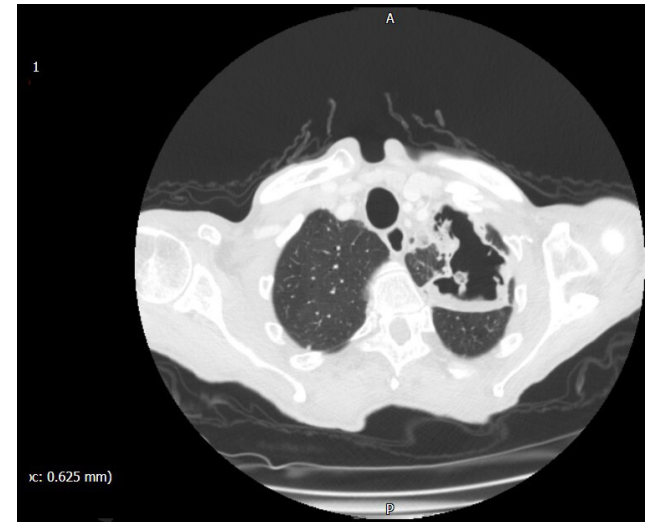

Figure 2 CT scan of the neck and thorax with contrast showing chronic infection within the left upper lobe with a large cavity containing organising material.

fever is uncommon and symptoms are often indolent or absent until late in the disease. Chronic pulmonary aspergillosis occurs in individuals with an underlying lung condition, such as COPD, sarcoidosis or tuberculosis. Aspergillomas (rounded conglomerates of fungal hyphae, fibrin, mucus and cellular debris that arise in pulmonary cavities) can develop as a late manifestation and may result in haemoptysis. Allergic bronchopulmonary aspergillosis affects patients with bronchiectasis and cystic fibrosis. A. fumigatus is the most common species implicated in all pulmonary syndromes. Clinical findings are non-specific and include fever, cough and pleuritic pain. Diagnostic methods suggest that respiratory samples are better than blood for all

\section{Learning points}

Aspergillus causes a myriad of pulmonary disorders depending on the host immunity and ranges from allergic to invasive disease. The classic risk factor for invasive aspergillosis is neutropenia and angioinvasion is involved in its pathogenesis and dissemination. This case involves an immunocompetent individual, therefore a high index of suspicion is required in patients without the classical risk factors as early presentation is usually silent and nonspecific, fever uncommon and timely treatment is crucial for survival.

- Detection of the galactomannan antigen level via ELISA can be useful in making an early diagnosis.

- The aims of treatment are to improve symptoms, prevent or limit haemoptysis and prevent fibrosis formation. 
tests except beta-D-glucan. ${ }^{2}$ Itraconazole is the antifungal agent of choice, followed by voriconazole and posaconazole. ${ }^{3}$ Aspergillomas with localised disease can be managed with lobectomy in individuals with an adequate respiratory reserve.

Contributors LD wrote the article. EM edited the article.

Funding The authors have not declared a specific grant for this research from any funding agency in the public, commercial or not-for-profit sectors.

Competing interests None declared.

Patient consent for publication Obtained.
Provenance and peer review Not commissioned; externally peer reviewed.

\section{ORCID iD}

Louise Dunphy http://orcid.org/0000-0001-5499-415X

\section{REFERENCES}

1 Kosmidis C, Denning DW. The clinical spectrum of pulmonary aspergillosis. Thorax 2015;70:270-7.

2 Russo A, Giuliano S, Vena A, et al. Predictors of mortality in non-neutropenic patients with invasive pulmonary aspergillosis: does galactomannan have a role? Diagn Microbiol Infect Dis 2014:80:83-6.

3 Singh N, Singh NM, Husain S, et al. Aspergillosis in solid organ transplantation. Am J Transplant 2013:13 Suppl 4:228-41.

Copyright 2020 BMJ Publishing Group. All rights reserved. For permission to reuse any of this content visit

https://www.bmj.com/company/products-services/rights-and-licensing/permissions/

BMJ Case Report Fellows may re-use this article for personal use and teaching without any further permission.

Become a Fellow of BMJ Case Reports today and you can:

- Submit as many cases as you like

- Enjoy fast sympathetic peer review and rapid publication of accepted articles

Access all the published articles

Re-use any of the published material for personal use and teaching without further permission

Customer Service

If you have any further queries about your subscription, please contact our customer services team on +44 (0) 2071111105 or via email at support@bmj.com.

Visit casereports.bmj.com for more articles like this and to become a Fellow 